FUNDAMENTO PARA TECNOLOGIAS DE LAVAGEM DE SOLO DE ÁGUA PELO REGULAMENTO DE CRESCIMENTO

\title{
RATIONALE FOR WATER SOIL WASHING TECHNOLOGIES BY GROWTH REGULATION
}

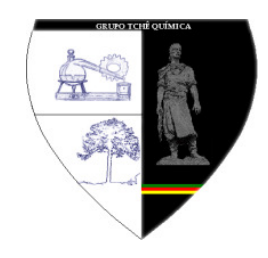

\section{ОБОСНОВАНИЕ ТЕХНОЛОГИИ ПРОМЫВОК ЗАСОЛЕННЫХ ПОЧВ ПУТЕМ РЕГУЛИРОВАНИЯ ГРУНТОВЫХ ВОД}

\author{
SIETKAZIEV, Adeubai S. ${ }^{{ }^{*}}$; KULKAEVA,Laura A. ${ }^{2}$;SHINYSHEROVA,Gaziza B. ${ }^{3}$ \\ ${ }^{1}$ Taraz State University named after M.Kh. Dulati, Department of Melioration and Agronomy, 60 Tole bi Str., zip \\ code 081100 , Taraz - Republic of Kazakhstan
}

(phone:+77477403414)

${ }^{2}$ Taraz State Pedagogical University, Department of Biology and Methods of Teaching Biology, 62 Tole bi Str., zip code 081100, Taraz - Republic of Kazakhstan

(phone: +77779431182 )

${ }^{3}$ Kazakh National Pedagogical University named after Abay, Department of Botany and General Biology, 13 Dostyk Ave., zip code 050010, Almaty - Republic of Kazakhstan

(phone: +77024200781 )

${ }^{*}$ Corresponding author

e-mail: adeubai@mail.ru

Received 01 December 2017; received in revised form 09 February 2018; accepted 21 May 2018

\section{RESUMO}

Quando a irrigação da terra na zona árida, um dos elementos obrigatórios para manter o equilíbrio entre sais e água é a lavagem do solo. Atualmente, os padrões de lavagem são calculados e recomendados para diferentes solos. No entanto, esses cálculos são baseados principalmente em dados experimentais. Para aumentar a eficiência da lavagem, e também para economizar água de irrigação, é necessário investigar o mecanismo de dessalinização do solo durante a lavagem. Neste artigo, propomos um método para calcular a taxa e o grau de dessalinização de solos com base na análise do movimento de partículas de sais. O principal elemento de cálculo é a velocidade e o alcance das partículas de sais em solução. Este método permite justificar e determinar a tecnologia de lixiviação de solos salinos. $O$ artigo apresenta os resultados da aplicação de métodos de modelagem matemática ao exemplo da margem esquerda do Maciço de Irrigação de Tentek. A base da modelagem foi colocada na equação básica da transferência de sais, com o cálculo dos coeficientes incluídos nela de acordo com os dados reais. Como resultado, as taxas líquidas de lavagem foram obtidas para as terras salinas, dependendo das propriedades físico-químicas dos solos do maciço investigado.

Palavras-chave: solo, águas subterrâneas, salinidade, irrigação.

\section{ABSTRACT}

When irrigation of land in the arid zone, one of the mandatory elements for maintaining the water-salt balance is soil washing. At present, washing standards are calculated and recommended for different soils. However, these calculations are based mainly on experimental data. To increase the efficiency of washing, and also to save irrigation water, it is necessary to investigate the mechanism of desalinization of the soil during washing. In this paper, we propose a method for calculating the rate and degree of desalination of soils based on the analysis of the motion of salt particles. The main calculation element is the velocity and range of the particle's salt in solution. This method makes it possible to justify and determine the technology of clock leaching of saline soils. The paper presents the results of applying mathematic modeling methods to the example of the left-bank Tentek Irrigation Massif. The basis of the modeling was laid the basic equation of salt 
transfer with the calculation of the coefficients included in it according to the actual data. As a result, net wash rates were obtained for saline lands, depending on the physicochemical properties of the soils of the investigated massif.

Keywords: soil, groundwater, salinity, irrigation.

\section{АННОТАЦИЯ}

При орошении земель в аридной зоне одним из обязательных элементов поддержания водносолевого баланса является промывка почвы. В настоящее время для различных почв рассчитаны и рекомендованы промывные нормы. Однако эти расчеты базируются главным образом на экспериментальных данных. Для повышения эффрективности промывки, а также экономии поливной воды необходимо исследовать механизм рассоления почвы при их промывании. В данной работе предлагается метод расчета скорости и степени опреснения почв на основе анализа движения частиц соли. При этом основным расчетным элементом является скорость и дальность пробега частицы соли в растворе. Данной метод позволяет обосновать и определить технологию тактовых промывок засоленных почв. В работе представлены результаты применения методов метаматического моделирования на примере левобережного Тентекского массива орошения. В основу моделироввания было положено основное уравнение солепереноса с расчетом входящих в него коэффициентов по фактическим данным. В результате были получены значения нетто промывной нормы на засоленных землях в зависимости от фризико-химических свойств почв исследуемого массива.

Ключевые слова:почва, грунтовые воды, засоленность, орошение.

\section{INTRODUCTION}

A huge problem for agriculture in irrigation is the salinization of soils. Low agricultural potentials of soil in warm regions are very saline. $20 \%$ of the irrigated land in the world is grown under irrigation and aggravates the problem, which leads to secondary salinization (Blaylock, 1994). Salts accumulate in the soil when there is little precipitation from the soil profile to leach ions, which leads to soil salinity (Glick, 2007).

Shallow groundwater is the main factor affecting migration, accumulation, and isolation of soil salt. With the subsequent impact on the growth, development, and distribution of vegetation in groundwater, it can easily lead to variability in the water content of water and salts (An et al., 2001; Yin et al., 2015). The hydrological cycle and the physical processes of soil water are closely related to soil water and the transfer of groundwater, which is an important area of research (Jie et al., 2011; Zhang et al., 2013; Chaudhuri and Ale, 2014). The conditions of water and salt in the soil are affected by the hydraulic connection between groundwater (Nippert et al., 2010; Xie et al., 2013). In the development of the dynamic law for soil water, soil salt and groundwater, there are means and methods of research (Deng et al., 2015; Wichelns and Qadir, 2015; Jordán et al., 2004). The understanding of soil water and groundwater and their interrelationships led to increased research in the hydrological cycle (Ruan et al., 2008; Wu et al., 2009; Ibrakhimov et al., 2007). Groundwater reaches the soil layers with a capillary ascending flow and then can penetrate into the soil water cycle. To understand the migration of soil water and salt, as well as groundwater, studies were conducted from single-processor analysis to complex multiprocess analysis (Wu et al., 2009).

Excessive salinity or insufficient saltwater irrigation can lead to water and salt stress combinations that can lead to secondary salinization and a number of environmental problems (Ruan et al., 2008; Wu et al., 200). The watering of saline waters, their dynamics and the distribution of soil salts have been extensively studied (Glick, 2007; Ruan et al., 2008; Ibrakhimov et al., 2007; Ibrahimi et al., 2014; Duan et al., 2015). Distributions of soil salts during watering saline waters have been solved dynamic models with water salt (Ruan et al., 2008).

Agricultural land is estimated by scientists, worldwide $20 \%$ of the total number of cultivated and $33 \%$ of irrigated suffer from high salinity. Irrigation with salt water and poor cultural practices, low precipitation at a rate of $10 \%$ per year, growing areas of saline soils. By 2050, it is estimated that more than $50 \%$ of the arable land will be saline (Jamil et al., 2011).

At the present time, the geography of the 
distribution of saline soils has been established. The composition of salts is studied depending on the factors of soil formation, geochemical and hydrological conditions, the technology of irrigation regimes. Resource-saving directions of amelioration of saline soils have been developed: washing, drainage, deep loosening, the influence of sorbents, chemical and phytomelioration of lands. At the present stage, the more economical technologies for controlling mass transfer, water and salts on irrigated soils under meliorative and operational regimes become relevant. To solve this problem, it is worthwhile to develop a set of physicomathematical problems that will describe the laws of their movement and distribution in the root layer of soils, quantify the content of salts in the soil.

When irrigation of land in the arid zone, one of the mandatory elements for maintaining the water-salt balance is soil washing. At present, washing standards are calculated and recommended for different soils. However, these calculations are based mainly on experimental data. To increase the efficiency of washing, and also to save irrigation water, it is necessary to investigate the mechanism of desalinization of the soil during washing.

Water reclamation includes the production process such important components of the ecosystem as soil, water and plants closely associated with water, energy and substance flow. Soil degradation, destruction of natural landscapes, decrease in productivity of reclaimed lands, depletion, and pollution of aquatic ecosystems put forward ecological aspects of water reclamation development in a number of priority areas.

Water is often the source of pollution on irrigated lands. Used for watering from contaminated water bodies.

In this regard, in the development of agriculture, it is necessary to form an environmentally sound strategy for the implementation of integrated land reclamation. Comprising the following basic principles:

- optimization of moisture supply of agricultural crops with the maximum use of natural moisture reserves and minimum irrigation water costs;

- rational scientifically grounded use of water for reclamation;

The study of soil processes makes it possible to obtain a more complete picture of the properties of the soil itself. On the one hand, the soil properties determine the soil process, on the other - the soil processes form new soil properties.

Pollution of soils in the form of salinization is mainly due to man's anthropogenic activity, with improper work on land improvement, agrotechnical and meliorative measures. This occurs as a result of ignoring the implementation of interrelated laws that regulate the natural equilibrium of soil evolution, as well as hydrogeological, hydrochemical and geochemical interactions in conducting environmental and meliorative work.

On the basis of data on the soil and ecological conditions of the chernozem-meadow and dark chestnut carbonate soils, there is a need to regulate the water regime of the root zone, as the main factor of moisture and salt transfer in the aeration zone of soils.

The solution of a number of important geo-ecological and meliorative problems is related to the need for reliable quantitative prediction of plant productivity under different climatic conditions and dietary regimes. The main problems are as follows: rationale for decisions on the rational use of the resources of the biosphere. Activities on environmental protection, development of the water-saving technology of saline and irrigated lands, improving the justification of land reclamation systems, etc.

The purpose of creating conditions for improving the soil-forming process ensuring the possibility of extended reproduction of soil fertility in the process of geoecosystem. For this purpose, it is necessary to maintain the automorphic regime of soil formation, groundwater to maintain at a sufficiently great depth to prevent the possibility of secondary salinization of soils at the minimum cost of irrigation water.

The main task of washing saline soils is desalinization of the root layer with a minimum amount of water. Washing the soils with an excessive washing rate can reduce their fertility and worsen the meliorative-ecological state of the irrigated massif studied.

\section{MATERIALS AND METHODS}

The most cost-effective means of 
combating saline soils is the creation of a downward flow of water in the root zone.

To regulate the water and salt regimes of soils during the development of saline and salinized irrigated lands and to prevent them from secondary salinization, a correct choice of irrigation regime and techniques for agricultural crops and a set of agrotechnical measures is necessary.

To justify the leaching norms, the following dependencies must be taken into account: the quality of the irrigation water of the cultivated crop, the number of irrigation, the uniformity of water distribution during irrigation, the water-permeability of the soil layer, and the drainage of the irrigation mass under study.

The results of studies on the mechanism of salt transfer in the conditions of the left bank of the Tentek Massif and the testing of technologic schemes for washing, taking into account the rate of infiltration flow with the use of permanent drainage against the background of temporary storage, are presented in Table 1.

The introduction of the experience of washing saline soils (soda-sulfate and sulfatesoda salinization) was carried out on the territory of Zhanaminskiy LLP in the Alakul District of the Taldykurgan Region. The total area of the experimental plot was 35 hectares (Figure 1).

The washing technology was carried out in the following sequence.

To substantiate the water-salt regime of saline soils of geo-ecosystems, complex studies were conducted on the following technologies:

The first way. Plowing of the field, layout, arrangement of platens, cutting of temporary irrigation and drainage on the background of permanent deep open drainage. Flushing water in checks. The area of checks is from 0.25 to 1.0 hectares.

The second way. Plowing of the fields is not performed, a deep loosening is carried out in a continuous way (in $0.5 \mathrm{~m}$ ). Depending on the water-physical properties, the depth of salinization of the compacted layers, it varies at a distance of $1.0-3.0 \mathrm{~m}$. In addition, temporary irrigation and temporary drainage are cut at a distance of $40-100 \mathrm{~m}$ with a depth of $0.8-1.0 \mathrm{~m}$. Deep loosening is carried out, thus, in the direction of the irrigator and perpendicular to the temporary drainage, leaving a distance of 10-15 $\mathrm{m}$ sometimes parallel, depending on the slope of
The third way. Plowing is underway, planning. Organic fertilizers (manure) are introduced 20-30 t/ha, then deep uniaxial loosening is carried out. In this case, the tractor must be moved in parallel with the loosened strip. The moisture content of the soil should not exceed its lowest moisture capacity. Otherwise, the already loosened layers will be compacted.

The main methods for regulating the hydrochemical regime are the effects on the groundwater table by various measures (irrigation, washing, loosening of soils on the background of drainage). The formation of watersalt, heat and food regimes in the calculated soil layer is directly affected by water-physical and physicochemical processes. The main parameters of systematic horizontal drainage are the distances between drains. The groundwater level (GWL) after draining, the pressure between the drains, the flow of groundwater to the drain and the collector. The inflow and flow of water to the drain from both sides are determined by the Equation 1 (Yin et al., 2015; Jie et al., 2011; Zhang et al., 2013; Chaudhuri and Ale, 2014):

$$
Q_{0}=4 k h^{2} l / R
$$

where $Q$ is the drain of water to the drain, $\mathrm{m}^{3} ; \mathrm{k}$ is the filtration coefficient, $\mathrm{m} /$ day; $\mathrm{h}$ - head of groundwater between drains, $m$; l- the length of the drain, $\mathrm{m}$; $\mathrm{t}$ - duration of washing, day; $\mathrm{R}-$ the distance between drains, $m$.

The inflow of water to the drain per hectare per unit of time is determined by the Equation 2:

$$
q_{0}=\frac{Q_{0}}{t}
$$

where $q_{0}$ is the drainage module at a given head of groundwater, $\mathrm{m}^{3} / \mathrm{ha}$.

Then, for a known value of the actual water velocity $\mathrm{Vf}$ of the soil, it is easy to determine the net wash rate of saline soils according to the following Equation 3 (An et al., 2011; Yin et al., 2015; Jie et al., 2011; Zhang et al., 2013; Chaudhuri and Ale, 2014; Nipper et al., 2010; Xie et al., 2013):

$$
N_{n m}=\frac{Q_{0} V_{f}}{q_{0}}
$$

Where $\mathrm{N}_{\mathrm{nm}}$ - washing rate (net), $\mathrm{m}^{3} / \mathrm{ha} ; \mathrm{V}_{\mathrm{f}}$ 
- the speed of filtration in saturated layers, $\mathrm{m} /$ day.

In the types of irrigation under consideration, it is first of all necessary to take into account the moisture reserves in the root zone, to sow certain crops. The greatest effect of the proposed activities will be achieved if the ecological and ameliorative measures are carried out against a backdrop of deep loosening.

To improve the ecological condition of lands and efficient use of water resources in irrigated areas, and also with the use of hydrothermal soil regime, it is possible to establish total water consumption with minimum water consumption, and wash the salinity of the soil by the following washing Equations 4 and 5 (Nippert et al., 2010; Xie et al., 2013; Deng et al., 2015):

$N_{S}=100 H \cdot \gamma \cdot \beta_{H B}$

$$
N_{B}=N_{T} \exp (-g \cdot \bar{R})
$$

Equating the Equations (4) and (5), we obtain Equation 6:

$N_{G}=100 H \gamma \cdot \beta_{H B}+N_{T} \exp (-g \cdot \bar{R})$

Where $N_{G}$ - general washing norms, $\mathrm{m}^{3} / \mathrm{ha} ; \mathrm{H}$ - calculated soil layer, $\mathrm{m}$; $\mathrm{N}_{\mathrm{s}}$ - water saturation, $\mathrm{m}^{3} / \mathrm{ha} ; \gamma$ - soil density, $\mathrm{t} / \mathrm{m}^{3} ; \mathrm{N}_{\mathrm{T}}-$ warm water for washing, $\mathrm{m}^{3} / \mathrm{ha} ; \beta_{\mathrm{HB}}$ - the lowest moisture capacity of the soil, $\% ; \mathrm{N}_{\mathrm{B}}$ - washing rates for displacement of salts from the calculated layer, $\mathrm{m}^{3} / \mathrm{ha} ; \mathrm{g}$ - intensity of evaporation in fractions; $\bar{R}$ - the change in the index of the hydrothermal regime under the influence of irrigation or washing norms $\left(\bar{R}=R /\left[L\left(O_{c}+N_{p}\right)\right]\right)$ (Yin et al., 2015; Jie et al., 2011; Nippert et al., 2010; Xie et al., 2013; Deng et al., 2015; Wichelns and Qadir, 2015); $\mathrm{N}_{\mathrm{p}}$ - single wash rate depending on the mechanical composition of soils, $\mathrm{m}^{3} /$ ha.

\section{RESULTS AND DISCUSSION:}

Water-physical properties of the soil of the massif were studied at 16 experimental sites, 11 of them are characterized by non-saline varieties of soils. A 5-strongly saline soils and salt marshes, which require the development of flushing and combined with experimental sites to study the salinity of soils.

The lowest humidified horizon, bound by the roots of plants, has the lowest density. The upper humus horizon has the following density, depending on the variety of soils $\left(\mathrm{t} / \mathrm{m}^{3}\right)$ : meadowmarsh 0.86-1.34; meadow areas 0.99-1.46; graygreen meadow 1.24-1.42; meadow-gray-green 1.21-1.44; sierozems are light 1.2-1.26; light chestnut 1.44-1.56.

The airborne porosity in the meter layer fluctuates: in light chestnut soils $10-24 \%$, in serozems $13-22 \%$, in meadow-serozem soils 11 $28 \%$, in serozem-meadow soils $22-30 \%$, in meadow soils $18-28 \%$, in meadow-bog soils 12 $24 \%$.

By the result of studying the waterphysical properties of soils, it is established that they belong to medium loamy and loamy to the level of groundwater and sandy loamy sand deposits are introduced by the wind. The fields are flat, enough to align long-base plans. Previous crops were sugar beet, corn.

According to the analysis of mineralization of irrigation water is $1.5-2 \mathrm{~g} / \mathrm{l}$, it can be used only on heavily saline lands, and it is unsuitable for irrigation. The outflow of ground and groundwater is absent, therefore it is necessary to build a deep horizontal $(3.0-3.5 \mathrm{~m})$ or closed drainage. Without this, it is impossible to lower the level of groundwater, which ranges from sowing to harvesting from $0.8-1.5 \mathrm{~m}$, that is very close to the surface of the earth.

To accelerate the leaching of harmful salts with washing water, in addition to the drainage located at a depth of $3.5 \mathrm{~m}$ at a distance of 100 $150 \mathrm{~m}$ from each other, temporary drains were cut at a depth of $0.8-1.2 \mathrm{~m}$ at a distance of $50-80$ $\mathrm{m}$ and a deep loosening of $0.8-1.0 \mathrm{~m}$ the leaching of salts increased 2.5-3.0 times, the removal of wash water by $30-35 \%$ was accelerated. the washing time was reduced by a factor of 3 , compared with conventional technology.

On reclaimed lands, especially where there is a danger of salinization. It is necessary to regulate water-salt and food regimes in order to improve the hydrochemical conditions of growing plants. Especially, this acute problem is revealed when carrying out complex hydro technical measures, such as washing the soil against the background of drainage. Recently, mathematical models have been widely used in melioration, 
which makes it possible to predict the water-salt regime of soil soils for the period of washing and operation of irrigated lands. For the prediction of the water-salt regime for the operational period, the main obstacle is the lack of reliable experimental data, obtained for soils with different water-physical properties. In this paper, we present the results of applying mathematical modeling methods to the example of the left-bank Tentek Irrigation Massif.

The results of studies on the mechanism of salt transfer in the conditions of the left bank of the Tentek Massif and the testing of technologic schemes for washing, taking into account the rate of infiltration flow with the use of permanent drainage against the background of temporary storage, are presented in Table 1.

The introduction of the experience of washing saline soils (soda-sulfate and sulfatesoda salinization) was carried out on the territory of "Zhanaminskiy" LLP in the Alakul District of the Taldy-Kurgan Region. The total area of the experimental plot was 35 hectares.

Before plowing the fields, phosphogypsum (6-8 t/ha) was added to the soil in combination with organic fertilizers (20-30 t/ha). They made plowing of the field to a depth of $30-35 \mathrm{~cm}$ with a plant plow (PPN-40). For the processing of compacted soil layers loosening was carried out on the depth of $60-70 \mathrm{~cm}$ using the $\mathrm{RN}-80 \mathrm{~B}$ ripper. The layout of the field was made by the long-term planner P-2.8.

The device of rollers of washed checks with a height of $35-40 \mathrm{~cm}$ was carried out with the help of rollers KZU-0.3D and cutting of temporary irrigators-trenchers KZU-0.3 with a trailer DT-75; cutting of the temporary drone with a depth of 1$1.2 \mathrm{~m}$ - a ditch digger (MK-16) with tractor K-701 (Blaylock, 1994; Glick, 2007; An et al., 2011; Yin et al., 2015; Jie et al., 2011; Zhang et al., 2013; Chaudhuri and Ale, 2014).

Washing was done around the clock. To ensure the effectiveness of washing irrigation and taking into account the soil filtration coefficient, the washed areas were broken into checks. The size of the checks depends on the slope of the planned field and the properties of the soils. The area of checks is from 0.125 to 1.0 hectares. The temporary drains were cut at a distance of 25 to $50 \mathrm{~m}$. Group temporary drains were constructed with distances of $200-300 \mathrm{~m}$. Checks were filled with water until a layer of $10-12 \mathrm{~cm}$ was created.

Washing began from the middle of the interdigitation and moved to the drains. Water from the temporary sprinkler was fed automatically to each check. The interval between two single irrigation constituted the following relationships: at a single rate of 800$1000 \mathrm{~m}^{3} /$ ha (sizes of checks $0.125-0.5$ hectares) of soil light loamy - 3-4 days; at medium loamy 5-6 days and with heavy loamy soil $-7-8$ days.

Practice shows: plowing with loosening accelerates the washing season, then in the usual way, 2.5-3 times, respectively, and preserves the fertility of the soil from the removal of all mineral and organic substances. And also, promotes rapid movement of soluble concentrations of harmful salts in the calculated layer. The tractor, passing through the loosened strip, simultaneously covers the upper layers of the soil, which facilitates the introduction of dissolved salt concentrations.

At the same time, soil fertility is preserved, water-physical properties of soils are improved. Consequently, for the regulation of water-salt and alimentary regimes, while maintaining and restoring soil fertility, the most effective and active means is a deep loosening of soils on unfavorable lands.

Deep loosening and temporary drainage is an effective tool for gypsum and heavy loamy solonchak soils. In LLP them. A. Sukhanbaev of the Zhambyl region, applying this method, washing was carried out with a rate of 5-8 thousand $\mathrm{m}^{3} /$ ha in gray-earth meadow medium loamy soils (Table 2 ).

To restore washed fields or unfavorable lands, they need to be enriched with organic substances, especially manure and green fertilizer. Green fertilizer is a constantly renewable source of organic matter; it helps fight against weeds and plant diseases, helps to reduce soil salinity, and protects the soil from erosion.

To obtain a positive effect after a deep digestion, it is necessary to apply organic fertilizer in a liquid form, because the deep layers are poor in nitrogen, the amount of which is 1.5-3 times less than other nutrients.

The introduction into the soil before or after washing manure or compost in an amount of 20-30 t/ha sharply increases the biological activity of the arable horizon. The carbon dioxide released from the decomposition of organic substances of manure facilitates the transfer of soil phosphates into soluble forms, and the 
enrichment of the surface layer with carbon dioxide significantly improves air nutrition of plants. Removal of salts from soils during irrigation recommended by warm water is presented in Table 2.

Removal of salts from soil with recommended watering with warm water (Glick, 2007; Deng et al., 2015; Wichelns and Qadir, 2015; Jordán et al., 2004; Ruan et al., 2013; Wu et al., 2009; Ibrakhimov et al., 2007; Ibrahimiet al., 2014; Duan et al., 2015; Jamil et al., 2011) is given in Table 3 , so the purpose of increasing the efficiency of washing the soils on the site is cut large and small furrows by alternating them, with the bottom of large furrows covered with a film of waterproof material. A surface of the wash area is covered with a transparent film stretched on a rigid frame. The latter is in the form of a cycloid whose lower axis of bending coincides with the axes of small furrows. Large furrows are periodically filled with mineralized waters, which are heated by the sun's rays and evaporate in the form of drops of non-mineralized water. They settle on the surface and overlap the films along the inner cycloidal surface of the level difference; they are filtered toward large furrows, thereby washing the soils.

With the irrigation and washing of saline soils, the salts are removed from the calculated layer. With the filtration waters, salts that are washed from the soils enter the groundwater. and then into the riverbeds. Evaporation from the surface of groundwater was determined by the method of water balance and processing of the material carried out in the study. She showed that the relationship between the evaporation of groundwater and the depth of occurrence of their level has an exponential pattern (Deng et al., 2015; Wichelns and Qadir, 2015; Jordán et al., 2004; Ruan et al., 2008).

Analysis of the water-salt balance of irrigated geosystems (the Tasotkelsky and Tentek Massifs) shows that with the existing technology of meliorative measures of optimal desalination of soils it is difficult to reach the required level of toxicity threshold. Therefore, more advanced reclamation methods are needed on the basis of new technical and technological means.

The results of the study are to determine the features of the studied landscapes, the soil types of which are gray-meadow and grayish, solonetzic, solonchaks. To study the hydrochemical regime of soils, differential formulas for the transfer of salts and moisture were used. On the basis of this formula, optimal washing rates for saline soils have been established.

At present, the following important questions are present in soil melioration, which are considered still unresolved and require special research to justify their values. They are as follows: determination of evaporation values from the surface of groundwater, the forecast of the salt regime in the irrigation period, the establishment of values for the critical level of groundwater level.

Evaporation from the surface of groundwater is the most important factor of salinization and water logging of soils. Therefore, the quantitative determination of its values for soil, having different water-physical properties is of great scientific importance.

To study evaporation from the surface of groundwater in each experimental area, five sites, devoid of vegetation, were identified. These sites differed in the salt content of soil and groundwater salinity. Conducted in the Tentek irrigation array in 1989-2001. The results show that a certain salinity of the soils corresponds to a certain mineralization of groundwater. If the average content of salts in the upper root zone of soils is not more than $0.30 \%$, then in such places the groundwater salinity varies from 2 to $5 \mathrm{~g} / \mathrm{l}$. In the case where the mean value of salt is in the soil $0.35 ; 0.6 ; 1.0 ; 1.5 ; 2 \%$ mean values of mineralization of groundwater, respectively, is 1.5; $2.0 ; 3 ; 5$ and $10 \mathrm{~g} / \mathrm{l}$.

Studies on the study of evaporation from the surface of groundwater were carried out in an experimental production plaza in July-August, after the third or fourth irrigation of sugar beet. The level of groundwater during the study period ranged from 0.9 to $3.8 \mathrm{~m}$ from the surface of the earth.

The data obtained are included in Table 3. From Table 3 and Figure 2 that the highest values of evaporation from the groundwater surface are observed when the groundwater level lies at a depth of more than one meter from the ground surface, and the lowest values are at a depth of about $2 \mathrm{~m}$ for the soils of group I and about $3 \mathrm{~m}$ for the remaining groups of soils.

The processing of the materials carried out in the table showed that the connection between the evaporation of groundwater and the depth of their level has an expansionary 
character and obeys the Equation 7 (Jordán et al., 2004; Ruan et al., 2008; Ibrakhimov et al., 2007; Ibrahimi et al., 2014; Duan et al., 2015; Jamil et al., 2011):

$$
E_{g}=E_{0}\left(1-\frac{H}{H_{m c}}\right) e^{-n H}
$$

where $E_{g}$ - evaporation of groundwater, $\mathrm{m} ; E_{\sigma}$ - evaporation surface of the soil, $\mathrm{m} ; H$ depth of groundwater; $H_{W L C}-$ water-lifting capacity of the soil, $\mathrm{m} ; n-$ a parameter that takes into account the water-physical properties of soils $(n=0.7-1.5)$.

The evaporation of groundwater $\left(E_{g}\right)$ is determined by Equation 8, and the evaporability of the soil surface $\left(E_{0}\right)$ is determined in the dependence of N.N. Ivanova (8) in Central Asia:

$$
E_{0}=0.0018(25+t)^{2}(100-a)
$$

Wher $\mathrm{t}-$ is the air temperature, ${ }^{\circ} \mathrm{C}$; $\mathrm{a}-$ relative humidity, $\%$.

\section{CONCLUSIONS:}

This technology was developed and implemented at the experimental production site of "Zhanama" in the Taldykurgan region, which has strongly soda-saline soils, and the type of salinity is sulfate-soda.

The results of the introduction of watersaving washing technology show that it is economically expedient to carry out rinsing 5-6 times with a single rate of $800-1000 \mathrm{~m}^{3} / \mathrm{ha}$ against the background of permanently operating drainage with the use of a temporary with an inter-distance of $40-100 \mathrm{~m}$ and a depth of $1.2 \mathrm{~m}$. At the same time, the total washing rates were $5000-8000 \mathrm{~m}^{3} / \mathrm{ha}$.

In comparison with the existing washing technology, this technology has the following effects:

- savings of washing water amounted to $35-40 \%$ of the total flow;

- desalination of soil in the root zone is 1.5-2.0 times more than in conventional technology;

- acceleration of washing in a short time in one season, more favorable salinity and reduced costs for evaporation.

It is recommended to carry out such a washing technology for at least three years and to cultivate in the washed fields appropriate salttolerant crops, taking into account the irrigation regime.

The efficiency of leaching of saline soils is directly dependent on soil preparation and, in particular, on the depth and method of plowing. Wash standards of saline soils are one of the main soil-ecological and agrotechnical measures that ensure the increase of agricultural crops. Therefore, the optimal setting of the norm. the tactics of washing irrigation and the ways of preparing the soil for conducting irrigation on saline lands is of great practical importance in increasing the yield of agricultural crops and improving the ecological state of irrigated geosystems.

\section{REFERENCES:}

1. An, L.S., Zhao, Q.S., Ye, S.Y., Liu, G.Q. Adv Water Sci., 2011, 22(5): 689-695.

2. Blaylock, A.D. Soil salinity, salt tolerance and growth potential of horticultural and landscape plants. University of Wyoming Extension Bulletin, 1994, Available at: http://www.wyomingextension.org/agpubs/pub s/WY988.PDF.

3. Chaudhuri, S, Ale, S. Sci Total Environ, 2014, 490, 379-390.

4. Deng, B.S., Wahap, H., Dang, J.H., Zhang, Y.P., Xuan, J.W., Arid Land Geo, 2015, 38(3), 599-607.

5. Duan, Y.H., Gan, Y.Q., Wang, Y.X., Deng, Y.M., Guo, X.X., Dong, C.J. J Geochem Explor, 2015, 149, 106-119.

6. Glick, B.R. Crit Rev Plant Sci., 2007, 26, 227242.

7. Ibrahimi, M, Miyazaki, T, Nishimura, T, Imoto, H. Arab J Geosci, 2014, 7(9), 3901-3911.

8. Ibrakhimov, M., Khamzina, A., Forkutsa, I., Paluasheva, G., Lamers, J.P.A., Tischbein, B. et al.Irrig Drainage Syst, 2007, 12(3-4), 219236.

9. Jamil, A., Raiz, S., Ashraf, M., Foolad, M.R.Critical Reviews in Plant Sciences, 2011, 30 (5), 435-458.

10. Jie, Z, van Heyden, J, Bendel, D, Barthel, R. Hydrogeol J., 2011, 19(8), 1487-1502.

11. Jordán, M. M., Navarro-Pedreno, J., GarcíaSánchez, E., Mateu, J., Juan, P. Environ 
Geol. 2004, 45 (4), 448-456.

12. Nippert, J., Butler, J.Jr., Kluitenberg, G., Whittemore, D., Arnold, D., Spal, S. et al.Oecologia, 2010, 162(2), 283-292.

13. Ruan, B. Q., Xu, F.R., Jiang, R.F. J Hydraul Eng, 2008, 39(5), 573-579.

14. Wichelns, D., Qadir, M. Agr. Water Manage, 2015, 157, 31-38.

15. Wu, Q. X., Zhu, J. Q., Liu, K.W. Hubei Agr.
Sci, 2009, 48 (3), 604-606.

16. Xie, W. P., Yang, J. S. J. Integr. Agric., 2013, 12 (4), 711-722.

17. Yin, L. H., Zhou, Y. X., Huang, J. T. J Hydrol. 2015, 528, 435-448.

18. Zhang, C. X., Liao, X. P., Li, J. L., Xu, L., Liu, M., Du, B. et al. Chemosphere, 2013, 92 (4), 337-343.

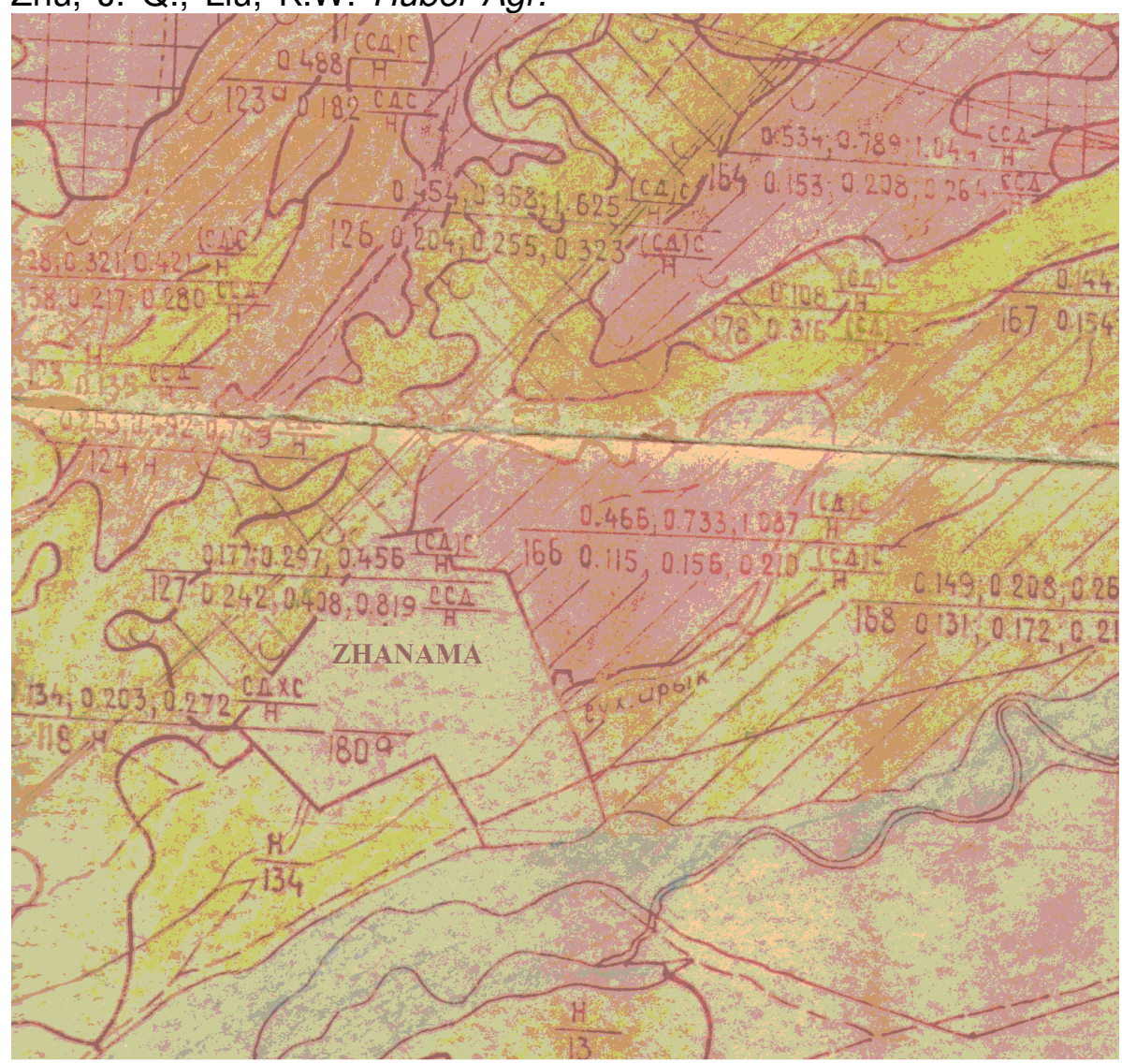

Figure 1. Soil-meliorative map of the experimental site

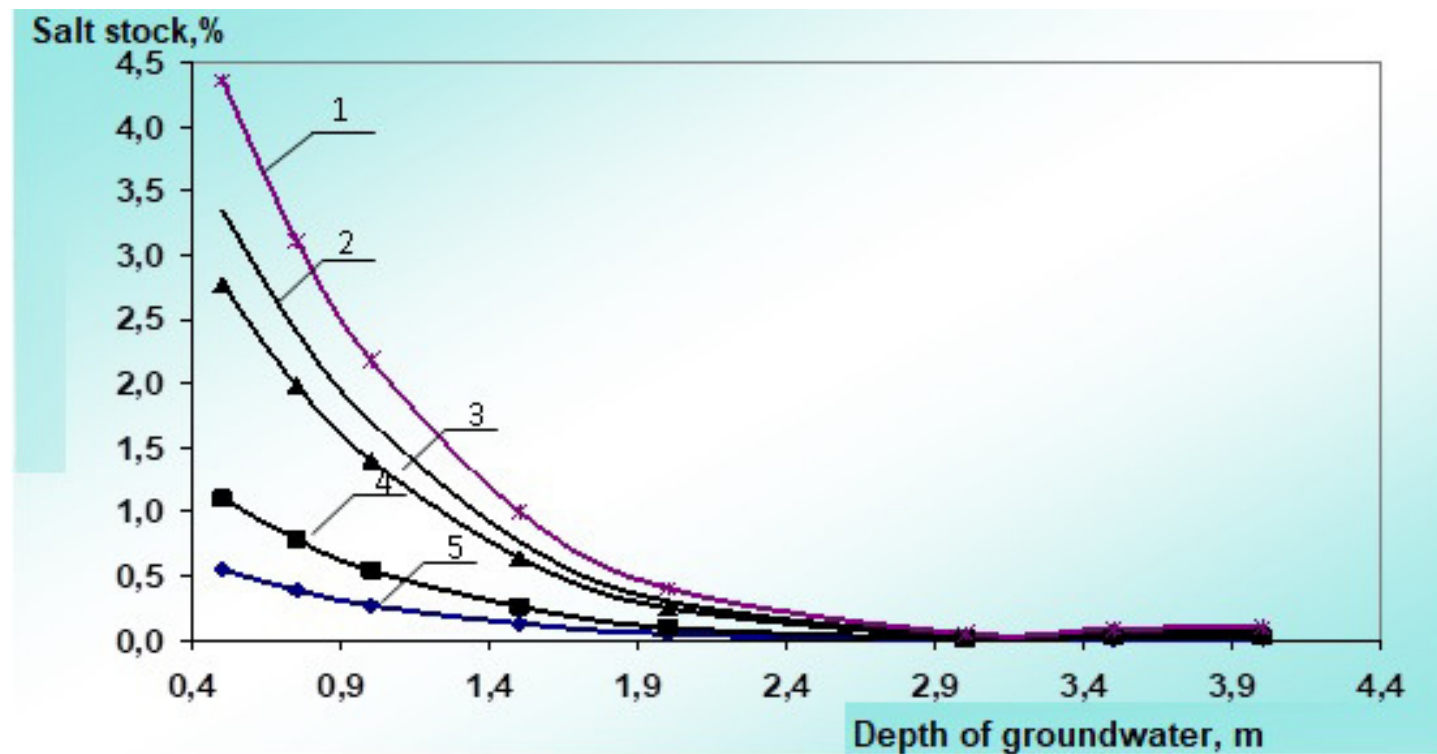

Figure 2. Stock of salts in the soil, depending on the depth of groundwater (1 - very strongly saline; 2 - highly saline; 3 - medium saline; 4 - slightly saline; 5 - not saline) 
Table 1. Effect of wash rates on leaching of salts from the soil in the experimental section "Zhanaminskiy", \% of the mass

\begin{tabular}{|c|c|c|c|c|c|c|c|c|c|c|}
\hline $\begin{array}{l}\text { Flushing } \\
\text { norms, } \\
\mathrm{m}^{3} / \mathrm{ha}\end{array}$ & $\begin{array}{l}\text { Soil } \\
\text { layer, } \\
\text { m }\end{array}$ & $\mathrm{HCO}_{3}$ & $\mathrm{CO}_{3}^{-}$ & $\mathrm{Cl}^{-}$ & $\mathrm{SO}_{2}^{-}$ & $\mathrm{Ca}^{+2}$ & $\mathrm{Mg}^{+2}$ & $\mathrm{Na}^{+}+\mathrm{K}^{+}$ & 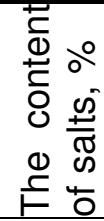 & 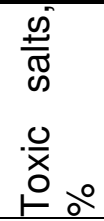 \\
\hline 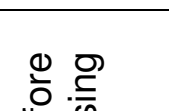 & $\begin{array}{l}0.4 \\
1.0 \\
1.0 \ldots 2.0\end{array}$ & $\begin{array}{l}0.0744 \\
0.0581 \\
0.0361\end{array}$ & $\begin{array}{l}0.2255 \\
0.0185 \\
0.0056\end{array}$ & $\begin{array}{l}0.2721 \\
0.2361 \\
0.2201\end{array}$ & $\begin{array}{l}0.8183 \\
0.7085 \\
0.3230\end{array}$ & $\begin{array}{l}0.0399 \\
0.0327 \\
0.0331\end{array}$ & $\begin{array}{l}0.0223 \\
0.0136 \\
0.0170\end{array}$ & $\begin{array}{l}0.5249 \\
0.4655 \\
0.2441\end{array}$ & $\begin{array}{l}1.7740 \\
1.5302 \\
0.8801\end{array}$ & $\begin{array}{l}1.6502 \\
1.4321 \\
0.8102\end{array}$ \\
\hline 6000 & $\begin{array}{l}0.4 \\
1.0 \\
1.0 \ldots 2.0\end{array}$ & $\begin{array}{l}0.0765 \\
0.0685 \\
0.0370\end{array}$ & $\begin{array}{l}0.0231 \\
0.0258 \\
0.0061\end{array}$ & $\begin{array}{l}0.1551 \\
0.0671 \\
0.1310\end{array}$ & $\begin{array}{l}0.3522 \\
0.3002 \\
0.2450\end{array}$ & $\begin{array}{l}0.0146 \\
0.0128 \\
0.0130\end{array}$ & $\begin{array}{l}0.0079 \\
0.0068 \\
0.0045\end{array}$ & $\begin{array}{l}0.2841 \\
0.2060 \\
0.1970\end{array}$ & $\begin{array}{l}0.9134 \\
0.6903 \\
0.6402\end{array}$ & $\begin{array}{l}0.8660 \\
0.5580 \\
0.6001\end{array}$ \\
\hline 8000 & $\begin{array}{l}0.4 \\
1.0 \\
1.0 \ldots 2.0\end{array}$ & $\begin{array}{l}0.0777 \\
0.0694 \\
0.0387\end{array}$ & $\begin{array}{l}0.0251 \\
0.0290 \\
0.0088\end{array}$ & $\begin{array}{l}0.0752 \\
0.0497 \\
0.1025\end{array}$ & $\begin{array}{l}0.2095 \\
0.2001 \\
0.2090\end{array}$ & $\begin{array}{l}0.0204 \\
0.0084 \\
0.0079\end{array}$ & $\begin{array}{l}0.0076 \\
0.0036 \\
0.0032\end{array}$ & $\begin{array}{l}0.1622 \\
0.1601 \\
0.1715\end{array}$ & $\begin{array}{l}0.5781 \\
0.5202 \\
0.5570\end{array}$ & $\begin{array}{l}0.5202 \\
0.3901 \\
0.5142\end{array}$ \\
\hline
\end{tabular}

Table 2. Determination of the washing norm of a meter layer of soils

\begin{tabular}{|c|c|c|c|c|}
\hline $\begin{array}{l}\text { Mechanical } \\
\text { composition }\end{array}$ & $\begin{array}{l}\text { Density of soil } \\
\gamma, \mathrm{t} / \mathrm{m}^{3}\end{array}$ & $\begin{array}{l}\text { Least } \\
\text { moisture } \\
\text { capacity } \beta_{\mathrm{HB}} \\
\%\end{array}$ & $\begin{array}{l}\text { Saturation } \\
\text { standards } \mathrm{N}_{\mathrm{S}}, \\
\mathrm{m}^{3} / \mathrm{ha}\end{array}$ & $\begin{array}{l}\text { Single wash } \\
\text { rates } \quad \mathrm{N}_{\mathrm{p}} \text {, } \\
\mathrm{m}^{3} / \mathrm{ha}\end{array}$ \\
\hline 1 & 2 & 3 & 4 & 5 \\
\hline Light & 1.33 & 16 & 2100 & 800 \\
\hline Medium & 1.45 & 22 & 3200 & 1100 \\
\hline Heavy & 1.52 & 26 & 3950 & 1300 \\
\hline PrecipitationO $\mathrm{p}_{\mathrm{p}}, \mathrm{m}^{3} / \mathrm{ha}$ & $\begin{array}{l}\text { Intensity } \\
\text { evaporation } \\
\text { fractions, g }\end{array}$ & $\begin{array}{l}\text { Hydrothermal } \\
\text { Coefficient, } R\end{array}$ & $\begin{array}{l}\text { Warm water for } \\
\text { washing } N_{T}, \mathrm{~m}^{3} / \mathrm{ha}\end{array}$ & $\begin{array}{l}\text { General washing } \\
\text { norms } N_{G} m^{3} / h a\end{array}$ \\
\hline 6 & 7 & 8 & 9 & 10 \\
\hline 230 & 0.13 & 2.45 & 3500 & 5600 \\
\hline 250 & 0.15 & 2.42 & 3500 & 6700 \\
\hline 270 & 0.20 & 2.39 & 4850 & 8800 \\
\hline
\end{tabular}


Table 3. Dependence of salt content on evaporation from the surface of groundwater (t/ha, \%)

\begin{tabular}{|c|c|c|c|c|c|c|c|c|c|c|c|}
\hline \multirow{3}{*}{$\begin{array}{l}\text { Mineralization } \\
\text { of } \\
\text { groundwater, } \\
\mathrm{g} / \mathrm{l}\end{array}$} & \multicolumn{2}{|c|}{$\begin{array}{l}\text { Initial } \\
\text { salinity, } \\
(0-1 \mathrm{~m})\end{array}$} & Grou & ndwate & $r$ table & & & & & & Notes \\
\hline & & & 0.5 & 0.75 & 1.0 & 1.5 & 2.0 & 3.0 & 3.5 & 4.0 & \\
\hline & $\%$ & t/ha & \multicolumn{9}{|c|}{ Evaporation from the groundwater surface, $\mathrm{m}^{3}$} \\
\hline \multirow[t]{2}{*}{ Clayey } & & & 1143 & 754 & 495 & 213 & 90 & 15.7 & 6.34 & 2.5 & \multirow[b]{2}{*}{$\begin{array}{l}Y=1.45 \\
t / m^{3} ; \\
n=1.5 \\
H_{w L C}= \\
6.5 m .\end{array}$} \\
\hline & & & & & & & & & & & \\
\hline 1.5 & 0.3 & 44 & 1.715 & 1.131 & 0.743 & 0.320 & 0.135 & 0.024 & 0.0095 & \multicolumn{2}{|l|}{$\begin{array}{l}0.0038 \\
0.0011\end{array}$} \\
\hline \multirow[t]{2}{*}{2} & 0.5 & 80 & 2.286 & 1.508 & 0.990 & 0.426 & 0.180 & 0.031 & 0.013 & \multirow{2}{*}{\multicolumn{2}{|c|}{0.0050}} \\
\hline & & & 0.829 & 0.547 & 0.359 & 0.154 & 0.065 & 0.011 & 0.0046 & \multirow{2}{*}{\multicolumn{2}{|c|}{$\begin{array}{l}0.0018 \\
0.0075\end{array}$}} \\
\hline \multirow[t]{2}{*}{3} & 0.6 & 87 & 3.429 & 2.262 & 1.485 & 0.639 & 0.270 & 0.047 & 0.019 & & \\
\hline & & & 0.994 & 0.656 & 0.431 & 0.185 & 0.078 & 0.014 & 0.0055 & \multirow{2}{*}{\multicolumn{2}{|c|}{$\begin{array}{l}0.0222 \\
0.010\end{array}$}} \\
\hline \multirow[t]{2}{*}{4} & 1.5 & 218 & 4.572 & 3.016 & 1.980 & 0.852 & 0.360 & 0.063 & 0.0254 & & \\
\hline & & & 2.486 & 1.640 & 1.077 & 0.463 & 0.196 & 0.034 & 0.014 & \multirow{2}{*}{\multicolumn{2}{|c|}{0.0054}} \\
\hline \multirow[t]{2}{*}{5} & 2 & 290 & 5.715 & 3.77 & 2.475 & 1.065 & 0.450 & 0.078 & 0.032 & & \\
\hline & & & 3.315 & $\begin{array}{l}2.187 \\
\end{array}$ & 1.436 & 0.618 & 0.261 & 0.046 & 0.018 & 0.0073 & \\
\hline
\end{tabular}

PERIÓDICO TCHÊ QUÍMICA•www.periodico.tchequimica.com• Vol. 15 N. 30.

- ISSN 1806-0374 (impresso) • ISSN 1806-9827 (CD-ROM) • ISSN 2179-0302 (meio eletrônico) (C) 2018. Porto Alegre, RS. Brasil 